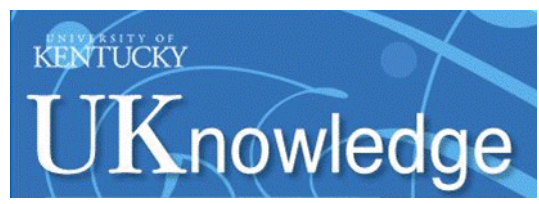

University of Kentucky

UKnowledge

$11-1995$

\title{
Nitrous Oxide Loss from Poultry Manure-Amended Soil after Rain
}

Mark S. Coyne

University of Kentucky, mark.coyne@uky.edu

A. Villalba

University of Kentucky

Robert L. Blevins

University of Kentucky

Follow this and additional works at: https://uknowledge.uky.edu/pss_facpub

Part of the Environmental Microbiology and Microbial Ecology Commons, and the Plant Sciences

Commons

Right click to open a feedback form in a new tab to let us know how this document benefits you.

\section{Repository Citation}

Coyne, Mark S.; Villalba, A.; and Blevins, Robert L., "Nitrous Oxide Loss from Poultry Manure-Amended Soil after Rain" (1995). Plant and Soil Sciences Faculty Publications. 16.

https://uknowledge.uky.edu/pss_facpub/16

This Article is brought to you for free and open access by the Plant and Soil Sciences at UKnowledge. It has been accepted for inclusion in Plant and Soil Sciences Faculty Publications by an authorized administrator of UKnowledge. For more information, please contact UKnowledge@lsv.uky.edu. 
Nitrous Oxide Loss from Poultry Manure-Amended Soil after Rain

Digital Object Identifier (DOI)

http://dx.doi.org/10.2134/jeq1995.00472425002400060007x

Notes/Citation Information

Published in Journal of Environmental Quality, v. 24, no. 6, p. 1091-1096.

The copyright holder has granted the permission for posting the article here.

This article is available at UKnowledge: https://uknowledge.uky.edu/pss_facpub/16 


\title{
Nitrous Oxide Loss from Poultry Manure-Amended Soil after Rain
}

\author{
M. S. Coyne, ${ }^{*}$ A. Villalba, and R. L. Blevins
}

\begin{abstract}
Land application of poultry wastes in Kentucky will increase as the broiler industry grows. If poultry manure stimulates $\mathrm{N}_{\mathbf{2}} \mathrm{O}$ loss from soil it will reduce the fertilizer $\mathrm{N}$ value of this waste. In contrast, stimulated $\mathrm{N}_{2} \mathrm{O}$ loss in grass filter strips receiving the runoff from manured fields could help reduce contamination of surface water by $\mathrm{NO}_{3}^{-}$. Our objectives were to determine (i) if poultry manure stimulated $\mathrm{N}_{2} \mathrm{O}$ loss in soil after rainfall and (ii) if there was an edge-of-field effect on $\mathrm{N}_{2} \mathrm{O}$ loss in grass filters intercepting runoff from amended soil. Soil covers were used to measure $\mathrm{N}_{2} \mathrm{O}$ loss from a well-drained, poultry manure-amended, silt loam soil immediately after simulated rainfall and were also used to measure $\mathrm{N}_{2} \mathrm{O}$ loss from grass filters intercepting their surface runoff. Nitrous oxide loss from manureamended soil was greater than from unamended controls and ranged from 5 to $13 \mathrm{mg} \mathrm{N}_{2} \mathrm{O}-\mathrm{N} \mathrm{m}^{-2} \mathrm{~h}^{-1}$. The maximum $\mathrm{N}_{2} \mathrm{O}$ loss was equivalent to $3.2 \mathrm{~kg} \mathrm{~N}_{2} \mathrm{O}-\mathrm{N} \mathrm{ha}^{-1} \mathrm{~d}^{-1}$. Nitrous oxide loss from grass filters intercepting runoff ranged from 0.1 to $1.4 \mathrm{mg} \mathrm{N}_{2} \mathrm{O}-\mathrm{N} \mathrm{m}^{-2} \mathrm{~h}^{-1}$ and was significantly greater than portions of the grass filters that did not intercept runoff. Nitrous oxide loss from poultry manureamended soils was greater than $\mathrm{N}_{2} \mathrm{O}$ loss typically measured from waste-amended agricultural soils. However, it only represented up to $0.7 \%$ of the total $\mathrm{N}$ in the applied manure.
\end{abstract}

$\mathrm{B}$ ROILER PRODUCTION IN KENTUCKY has dramatically increased in recent years and by 1997 annual production is expected to exceed 250 million birds. Because approximately $1500 \mathrm{~kg}$ of waste is generated per 1000 birds in a 10 -wk growing cycle, the waste generated by this industry's growth, both manure and litter, will be considerable (Edwards and Daniel, 1992).

Poultry wastes are typically land-applied in Kentucky, as in much of the southeastern USA, since this practice is cheap and convenient relative to processing methods such as composting. Crops can recover some of the $\mathrm{N}$ from the waste, which reduces the inorganic fertilizer $\mathrm{N}$ required to sustain high yields. However, compared with other animal wastes, relatively little is known about

Department of Agronomy, N-122 Agricultural Science Building-North, Univ. of Kentucky, Lexington, KY 40546-0091. Contribution of the Kentucky Agricultural Exp. Stn. Manuscript no. 94-3-11. Received 19 Oct. 1994. *Corresponding author (mscoyn00@ukcc.uky.edu).

Published in J. Environ. Qual. 24:1091-1096 (1995). the environmental effects of poultry waste disposal (Edwards and Daniel, 1992).

One environmental consequence of poultry waste disposal may be stimulation of nitrous oxide $\left(\mathrm{N}_{2} \mathrm{O}\right)$ loss from soil. Nitrous oxide contributes to global warming and ozone layer destruction (Davidson, 1991). However, in terms of $\mathrm{N}$ management, a more immediate interest is that it represents a largely irreversible loss of $\mathrm{N}$ from soil. Experiments employing poultry waste as a soil amendment have been conspicuously absent in studies of $\mathrm{N}_{2} \mathrm{O}$ loss from agricultural soil (Eichner, 1990). More importantly, few of these field studies measured $\mathrm{N}_{2} \mathrm{O}$ loss during periods when it was likely to be at its greatestimmediately after rain (Firestone and Tiedje, 1979).

Coyne et al. (1994) monitored $\mathrm{N}_{2} \mathrm{O}$ loss after simulated rainfall on a well-drained silt loam soil amended with stored poultry manure and measured rates that averaged $0.18 \mathrm{~kg} \mathrm{~N}_{2} \mathrm{O}-\mathrm{N} \mathrm{ha}^{-1} \mathrm{~d}^{-1}$. However, up to 3 wk elapsed between the date of manure application and rainfall simulation. Furthermore, it was not obvious from this study whether poultry manure stimulated $\mathrm{N}_{2} \mathrm{O}$ loss from soil relative to unamended soil. Evidence that recently incorporated fresh poultry manure stimulates $\mathrm{N}_{2} \mathrm{O}$ loss from tilled soils immediately after rainfall still needs to be examined.

Although $\mathrm{N}_{2} \mathrm{O}$ emission represents lost $\mathrm{N}$ from a nutrient management perspective, it would be beneficial in terms of reducing $\mathrm{NO}_{3}^{-}$contamination of surface water and groundwater by runoff from manured fields. Grass filters are used as a best management practice to intercept surface runoff before it reaches waterways. Groffman et al. (1991) noted that grass filters had greater denitrification potential than control soils, although they did not demonstrate this effect by measuring $\mathbf{N}$ gas loss in field conditions. They suggested that adding readily available $\mathrm{C}$, such as manure, might enhance denitrification in filter strips and remove some of the $\mathrm{NO}_{3}^{-}$that infiltrated grass filters before it reached groundwater (Groffman et al., 1991). Nitrous oxide is an intermediate in denitrification and other microbial pathways that reduce $\mathrm{NO}_{3}^{-}$; conse-

Abbreviations: ECD, electron capture detector; MPN, most probable number; $C O D$, chemical oxygen demand. 
quently, grass filters that trap runoff from manureamended soil may have elevated $\mathrm{N}_{2} \mathrm{O}$ loss and reflect increased denitrification activity.

Coyne et al. (1994) observed that $\mathrm{N}_{2} \mathrm{O}$ loss from grass filters receiving runoff from poultry manure-amended soil was less than in the manure-amended soil itself. However, the edge-of-field effect was not examined by comparing $\mathrm{N}_{2} \mathrm{O}$ loss from grass filters receiving runoff to suitable controls. Nitrous oxide loss may be stimulated in grass filters abutting manured plots and receiving their runoff compared with grass filters not similarly affected. If so, it represents a route by which $\mathrm{N}$ can be removed from surface runoff before it contributes to nonpointsource pollution of adjoining waterways or infiltrates to groundwater.

In this article we report on the stimulation of $\mathrm{N}_{2} \mathrm{O}$ loss from tilled soil amended with fresh, undercage layer manure immediately after a runoff-producing rain. We also report on the edge-of-field effect of runoff from manure-amended soil on $\mathrm{N}_{2} \mathrm{O}$ loss in adjoining grass filters. Our objectives were to quantify $\mathrm{N}_{2} \mathrm{O}$ loss immediately after rainfall in both cases and relate these measurements to the potential denitrification activity in both the manureamended soil and grass filter strips.

\section{MATERIALS AND METHODS}

Site. We did the study at the University of Kentucky Agricultural Experiment Station in Lexington during June and July 1993 on plots that were previously used by Coyne et al. (1994) for rainfall simulation studies. The soil was a well-drained, Maury silt loam soil (fine, mixed, mesic Typic Paleudalf) with an average natural slope of $9 \%$ and soil permeability ranging from 5 to $15 \mathrm{~cm} \mathrm{~h}^{-1}$ (Blevins et al., 1990). Six individual tilled plots $4.6 \mathrm{~m}$ wide by $18.2 \mathrm{~m}$ long (Plots 1 and 2) or $13.7 \mathrm{~m}$ long (Plots 3, 4, and 5) were prepared (Fig. 1). An additional $18.2 \mathrm{~m}$ long plot was prepared but rendered unusable by storm damage during this study. A grass filter strip either 9.0 or $4.5 \mathrm{~m}$ in length abutted the downslope edge of each tilled strip as shown in Fig. 1. These grass filters were a mixed sod composed of tall fescue (Festuca arundinacea L.) and Kentucky bluegrass (Poa pratensis L.).

Site Treatment. Moore et al. (1983) previously described the rain simulator used in our study. Due to its size (five individual units, hooked in tandem, each with dimensions of $4.6 \mathrm{~m}$ by $6.1 \mathrm{~m}$ ), the time necessary to prepare each plot for rain simulation, and the length of rain simulation on each plot, it was impractical to attempt more than one simulation per week. We minimized this temporal difference by strictly maintaining the same timing of manure application and rain simulation. Undercage poultry manure from a laying house was collected by $0900 \mathrm{~h}$ and uniformly spread over a tillage strip at $\mathbf{1 6 . 0}$ $\mathrm{Mg} \mathrm{ha}^{-1}$ (wet wt.). The manure was incorporated into the tillage strip to a depth of $15 \mathrm{~cm}$ with a chisel plow as the only tillage practice. Tillage was in the direction of the slope and was completed by $1200 \mathrm{~h}$. A border surrounding the manure-amended soil was tilled at the same time. We left the tillage strips uncovered after manure application unless rain was forecast. In that event, we covered the strips with black plastic tarps. We did not cover the grass filters. Meteorological conditions during the study are shown in Fig. 2.

The average nutrient composition of the manure was $2.8 \%$ total $\mathrm{N}, 2.9 \%$ total $\mathrm{P}$, and $1.8 \%$ total $\mathrm{K}$ on a wet-weight basis. Average moisture content was $34 \%$. The rate used was equivalent to an application of $448 \mathrm{~kg} \mathrm{~N} \mathrm{ha}^{-1}$, about three

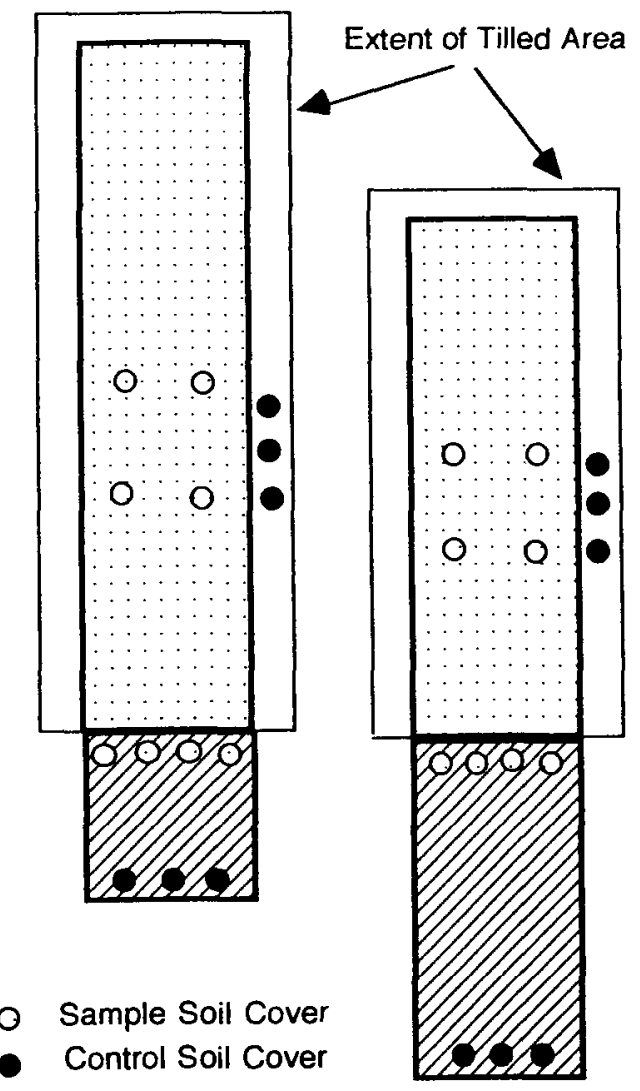

Manure Amended Strip

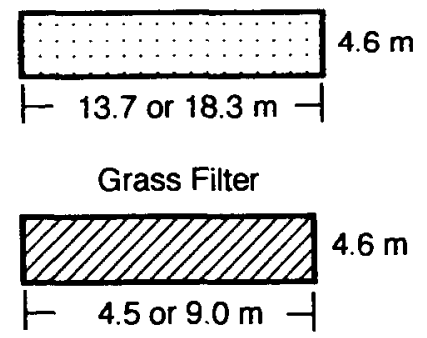

Fig. 1. Diagram of the research plots and location of the sample and control soil covers for $\mathrm{N}_{2} \mathrm{O}-\mathrm{N}$ loss measurements.

times the recommended $\mathrm{N}$ application rate for continuous corn (Zea mays L.) on this soil. The purpose of the high manure application rate was to simulate a worse-case scenario for surface runoff after rainfall.

We began rain simulation $48 \mathrm{~h}$ after manure application. The dates of rain simulation are in Table 1 . Simulated rain was applied simultaneously to the entire length and width of each tillage strip and grass filter strip. This included the unamended but tilled border area. The rain simulation rate was $6.4 \mathrm{~cm} \mathrm{~h}^{-1}$. The intensity of this rain approximates a 1-in-10-yr storm event in central Kentucky, but it was necessary to cause surface runoff onto the grass filters within a reasonable period.

We simulated rain until we obtained runoff from the bottom of the grass filters for at least $1 \mathrm{~h}$. Since each tillage strip had different runoff characteristics, and the grass filters were of different lengths, the duration of simulated rain varied from 


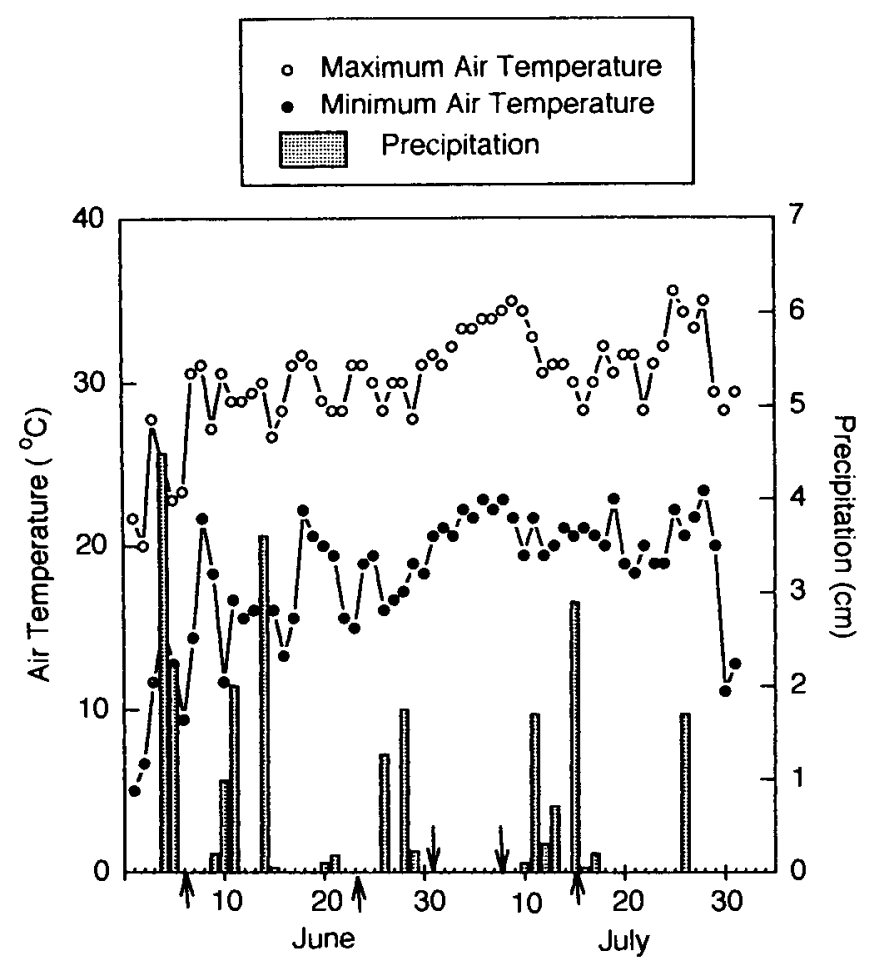

Fig. 2. Rain and air temperature during the study period. Arrows indicate dates of rainfall simulation.

plot to plot (Table 1). We usually observed surface runoff from the tillage strips 20 to 30 min after simulated rain began.

Soil Cover Measurements. We inserted soil covers to a depth of $2.5 \mathrm{~cm}$ in various locations in each plot to measure $\mathrm{N}_{2} \mathrm{O}$ loss immediately after simulated rain ceased (Fig. 1). Four soil covers were placed in the middle of the tillage strips. Four soil covers were placed in the grass filters within $1 \mathrm{~m}$ of the tillage strips. This was where maximum sediment trapping took place during surface runoff. Three soil covers were placed in tilled but unamended soil adjacent to each manureamended tillage strip (Fig. 1). An additional three soil covers were placed at the bottom of the grass filters approximately 4.0 or $8.5 \mathrm{~m}$ (depending on the filter strip length) from the interface with the tillage strips. These six soil covers were the controls against which we compared $\mathrm{N}_{2} \mathrm{O}$ loss from manureamended tillage strips and grass filters intercepting runoff.

The soil covers were coffee cans of $17.1 \mathrm{~cm}$ height and $15.6 \mathrm{~cm}$ diam. with the bottoms removed and a rubber septum penetrating the original plastic lid. The cans were not vented. Preliminary experiments indicated that the cans remained gas tight for the duration of field measurements. At $0,15,30$, and $60 \mathrm{~min}$, we removed $4.0-\mathrm{mL}$ gas samples from the soil cover head space and stored them, until $\mathrm{N}_{2} \mathrm{O}$ analysis, in pre-evacuated blood collection vials (vacutainers, Becton Dickinson, Rutherford, NJ). Though convenient, vacutainers have several drawbacks as storage containers: they are incompletely evacuated; they contain $\mathrm{N}_{2} \mathrm{O}$ in excess of atmospheric background $\left(0.31 \mu \mathrm{L} \mathrm{L}^{-1}\right)$; and $\mathrm{N}_{2} \mathrm{O}$ leaks through the rubber stoppers (Mosier and Klemedtsson, 1994). We took into account sample dilution in incompletely evacuated tubes during calculation of $\mathrm{N}_{2} \mathrm{O}$ flux and removed a time zero air sample for all flux measurements to correct for background $\mathrm{N}_{2} \mathrm{O}$ in the vacutainers as recommended by Mosier and Klemedtsson (1994). A preliminary experiment indicated that $\mathrm{N}_{2} \mathrm{O}$ loss from the vacutainers was $<10 \%$ when samples were analyzed within $1 \mathrm{wk}$, as was the case in this study.
Table 1. Conditions during rainfall simulations.

\begin{tabular}{|c|c|c|c|c|c|}
\hline \multirow[b]{2}{*}{ Plot } & \multirow{2}{*}{$\begin{array}{c}\text { Rain } \\
\text { simulation } \\
\text { date }\end{array}$} & \multirow{2}{*}{$\begin{array}{c}\text { Air } \\
\text { temperature }\end{array}$} & \multicolumn{2}{|c|}{$\begin{array}{c}\text { Soil } \\
\text { temperature } \dagger\end{array}$} & \multirow{2}{*}{$\begin{array}{c}\text { Minutes } \\
\text { of rain }\end{array}$} \\
\hline & & & Tilled strip & Filter strip & \\
\hline & & & ${ }^{\circ} \mathrm{C}-$ & - & \\
\hline $\begin{array}{l}1 \\
2 \\
3 \\
4 \\
5\end{array}$ & $\begin{array}{l}6 \text { June } \\
23 \text { June } \\
1 \text { July } \\
8 \text { July } \\
15 \text { July }\end{array}$ & $\begin{array}{l}28 \\
28 \\
30 \\
34 \\
29\end{array}$ & $\begin{array}{l}23 \\
24 \\
26 \\
29 \\
26\end{array}$ & $\begin{array}{l}22 \\
23 \\
24 \\
27 \\
24\end{array}$ & $\begin{array}{r}110 \\
92 \\
115 \\
205 \\
175\end{array}$ \\
\hline
\end{tabular}

† Mean of 10 measurements at the 0- to $15-\mathrm{cm}$ soil depth recorded immediately after rain simulation stopped.

Gas Analysis. We measured $\mathrm{N}_{2} \mathrm{O}$ with an electron capture detector (ECD) on a Varian 3700 gas chromatograph fitted with a $2 \mathrm{~m}$ Porapak $\mathrm{Q}$ column. Analysis conditions for the ECD were: detector temperature, $360^{\circ} \mathrm{C}$; column temperature, $60^{\circ} \mathrm{C}$; carrier gas, $95 \%$ argon, $5 \%$ methane; carrier gas flow

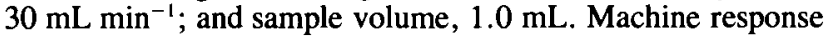
to $\mathrm{N}_{2} \mathrm{O}$ was measured and compared to $\mathrm{N}_{2} \mathrm{O}$ standards of known concentration. Rates of $\mathrm{N}_{2} \mathrm{O}-\mathrm{N}$ evolution were calculated based on the formula given by Hutchinson and Mosier (1981).

Soil Analyses. Immediately before rain simulation in each plot, 10 soil cores at depths of 0 to $5 \mathrm{~cm}$ were randomly collected from the length of the tillage strip and from the grass filters. The soil cores were composited by location (tillage strip or grass filter), crumbled, mixed thoroughly, and stored at $4^{\circ} \mathrm{C}$ until rain simulations were completed. Subsamples were removed to determine gravimetric water content before storage. These soil samples were used for the following analyses:

For analysis of $\mathrm{NO}_{3}^{-}$and $\mathrm{NH}_{4}^{+}$concentration in soil before rain simulation, subsamples were removed from the stored soil of each plot, uniformly mixed, extracted with a $1 \mathrm{M} \mathrm{KCl}$ ( $1: 2$, soil/extractant by weight), filtered to provide a soil-free supernatant, and analyzed using a Technicon Auto Analyzer System II.

We used the soil slurry method of Smith and Tiedje (1979) to measure potential denitrification activity in the stored soil samples of each plot. The soil slurry was prepared by combining $10 \mathrm{~g}$ soil (wet wt.) with $5 \mathrm{~mL}$ distilled water in a $125-\mathrm{mL}$ erlenmeyer flask. The flask was sealed with a ported rubber stopper and made anaerobic by evacuating and flushing three times with oxygen-free $\mathrm{N}_{2}$ gas. Reagent grade acetylene was added to the headspace of each flask to give a final concentration of $10 \%$. One of three treatments was imposed on each flask: an unamended control; addition of $0.5 \mathrm{mg} \mathrm{KNO}_{3}$ per flask; addition of $50 \mathrm{mg}$ glucose per flask. Each treatment was replicated four times from which a mean value was determined and used for final statistical analysis. Chloramphenicol was not used to prevent denitrification enzyme synthesis because of the short duration of the assay $(2 \mathrm{~h})$ during which de novo synthesis of denitrification enzymes was assumed to be insignificant (Smith and Tiedje, 1979). The flasks were incubated in a shaking water bath at $30^{\circ} \mathrm{C}$ and $1-\mathrm{mL}$ headspace samples were removed from each flask at 30 -min intervals for immediate analysis by gas chromatography as previously described.

We determined the denitrifier most probable number (MPN) in the stored soil samples of each plot using the procedure outlined by Tiedje (1982). A 10-fold serial dilution of soil in physiological saline $\left(8.5 \mathrm{~g} \mathrm{NaCl} \mathrm{L}^{-1}\right.$ in distilled $\left.\mathrm{H}_{2} \mathrm{O}\right)$ was used to inoculate five replicate tubes per dilution. Growth media was $15 \mathrm{~g} \mathrm{~L}^{-1}$ Tryptic Soy Broth containing $1 \mathrm{~g} \mathrm{~L}^{-1}$ $\mathrm{KNO}_{3}$. The tubes were sealed with rubber stoppers to facilitate development of denitrifying conditions and incubated $28 \mathrm{~d}$ at $26^{\circ} \mathrm{C}$. Residual $\mathrm{NO}_{3}^{-}$was detected with diphenylamine in con- 
Table 2. The $\mathrm{N}_{2} \mathrm{O}-\mathrm{N}$ evolution from tilled strips and grass filters after simulated rainfall.

\begin{tabular}{|c|c|c|c|c|c|}
\hline \multirow[b]{2}{*}{ Plot } & \multirow{2}{*}{$\begin{array}{c}\text { Rain } \\
\text { simulation } \\
\text { date }\end{array}$} & \multicolumn{2}{|c|}{ Tilled strip } & \multicolumn{2}{|c|}{ Grass filter } \\
\hline & & $\begin{array}{c}\text { Manure } \\
\text { amended } \dagger\end{array}$ & $\begin{array}{l}\text { Unamended } \\
\text { control } \ddagger\end{array}$ & $\begin{array}{c}\text { Receiving } \\
\text { runoff } \dagger\end{array}$ & Controlł \\
\hline & & & $-\mathrm{mg} \mathrm{N}_{2} \mathrm{O}-\mathrm{N}$ & $m^{-2} h$ & \\
\hline $\begin{array}{l}1 \\
2 \\
3 \\
4 \\
5\end{array}$ & $\begin{array}{l}6 \text { June } \\
23 \text { June } \\
1 \text { July } \\
8 \text { July } \\
15 \text { July }\end{array}$ & $\begin{array}{r}5.42 \pm 4.04 \\
13.16 \pm 0.22 \\
6.38 \pm 3.02 \\
7.40 \pm 3.99 \\
13.30 \pm 2.68\end{array}$ & $\begin{array}{l}5.62 \pm 1.78 \\
2.43 \pm 2.27 \\
2.00 \pm 0.97 \\
2.45 \pm 0.85 \\
0.46 \pm 0.23\end{array}$ & $\begin{array}{l}0.12 \pm 0.03 \\
0.07 \pm 0.13 \\
0.21 \pm 0.16 \\
1.24 \pm 0.27 \\
1.35 \pm 0.47\end{array}$ & $\begin{array}{l}0.01 \pm 0.07 \\
0.43 \pm 0.15 \\
0.09 \pm 0.02 \\
0.33 \pm 0.22 \\
0.15 \pm 0.09\end{array}$ \\
\hline
\end{tabular}

$\dagger$ Mean of four replicates +1 SD.

$\ddagger$ Mean of three replicates \pm 1 SD.

centrated sulfuric acid. Published tables (Alexander, 1982) were used to convert the results of the MPN assays to an estimate of the mean denitrifier population per gram of dry soil for each location.

Statistical Analysis. The data for field $\mathrm{N}_{2} \mathrm{O}$ loss were analyzed for statistical significance by one and two-way ANOVA using a completely randomized, replicated experiment design. Regression analysis was done using Microsoft Excel (Microsoft Corp., Redmond, WA). Potential denitrification activity in manure-amended tillage strips and grass filters was compared by means of $t$-tests.

\section{RESULTS AND DISCUSSION}

Our first objective was to determine the magnitude of $\mathrm{N}_{2} \mathrm{O}$ loss from poultry manure-amended soil immediately after rain. There were significant differences in $\mathrm{N}_{2} \mathrm{O}$ loss between plots $(P \leq 0.01)$, so these results are reported on an individual plot basis (Table 2). Nitrous oxide loss ranged from 5.4 to $13.3 \mathrm{mg} \mathrm{N}_{2} \mathrm{O}-\mathrm{N} \mathrm{m}^{-2} \mathrm{~h}^{-1}$ in the manure-amended soil. This is a conservative estimate. The soil covers were not vented and Hutchinson and Mosier (1981) showed that vented soil covers accumulate significantly more $\mathrm{N}_{2} \mathrm{O}$ than nonvented covers. This reflects the combined effects of reduced $\mathrm{N}_{2} \mathrm{O}$ diffusion from soil due to back pressure and the subsequent potential for further reduction of $\mathrm{N}_{2} \mathrm{O}$ to $\mathrm{N}_{2}$. The $\mathrm{N}_{2} \mathrm{O}$ losses we measured would also account for only part of the $\mathrm{N}_{2} \mathrm{O}$ formed under these conditions. Nitrous oxide is relatively soluble $\left(0.54-0.47 \mathrm{~mL} \mathrm{~N}_{2} \mathrm{O}\right.$ per $\mathrm{mL} \mathrm{H}_{2} \mathrm{O}$ between 25 and $30^{\circ} \mathrm{C}$ ) (Tiedje, 1982). Some of the $\mathrm{N}_{2} \mathrm{O}$ produced after rainfall would not have been measured because it was undoubtedly dissolved in soil water.

The rates were not correlated with any obvious parameters. Regression analysis indicated that neither the date of rain simulation (Table 1), duration of rain (Table 1), water-filled pore space, initial soil moisture content before rainfall (Table 3 ), initial $\mathrm{NO}_{3}^{-}$or $\mathrm{NH}_{4}^{+}$concentration (Table 3), nor potential denitrification activity were significantly correlated $(P \leq 0.05)$ with $\mathrm{N}_{2} \mathrm{O}$ loss from manure-amended soil. Spatial variability of $\mathrm{N}_{2} \mathrm{O}$ loss in the plots may have obscured statistically significant relationships since the average coefficient of variability in manure-amended soil was $39 \%$.

The $\mathrm{N}_{2} \mathrm{O}$ emission we measured was equivalent to daily $\mathrm{N}_{2} \mathrm{O}$ loss ranging from 1.3 to $3.2 \mathrm{~kg} \mathrm{~N}_{2} \mathrm{O}-\mathrm{N}$ $\mathrm{ha}^{-1} \mathrm{~d}^{-1}$. Cates and Keeney (1987) measured total $\mathrm{N}_{2} \mathrm{O}$ emission of 3.60 and $5.20 \mathrm{~kg} \mathrm{~N}_{2} \mathrm{O}-\mathrm{N} \mathrm{ha}^{-1} \mathrm{yr}^{-1}$ in manure-amended corn, whereas Goodroad and Keeney
Table 3. Soil $\mathrm{NO}_{3}^{-}-\mathrm{N}$ and $\mathrm{NH}_{4}^{+}-\mathrm{N}$ concentrations (oven dry weight soil basis) and gravimetric water content in the $0-$ to $5-\mathrm{cm}$ soil depth immediately before simulated rainfall.

\begin{tabular}{|c|c|c|c|c|c|c|c|}
\hline \multirow[b]{2}{*}{ Plot } & \multirow{2}{*}{$\begin{array}{c}\text { Rain } \\
\text { simulation } \\
\text { date }\end{array}$} & \multicolumn{3}{|c|}{ Tilled strip } & \multicolumn{3}{|c|}{ Grass filter } \\
\hline & & $\begin{array}{l}\text { Percent } \\
\text { moisture }\end{array}$ & $\mathrm{NO}_{3}^{-}-\mathrm{N}$ & $\mathrm{NH}_{4}^{+}-\mathrm{N}$ & $\begin{array}{l}\text { Percent } \\
\text { moisture }\end{array}$ & $\mathrm{NO}_{3}^{-}-\mathrm{N}$ & $\mathrm{H}_{4}^{-}-\mathrm{N}$ \\
\hline & & & — $\mathrm{mg}$ & $\mathrm{kg}^{-1}$ & & - $\mathrm{mg} \mathrm{k}$ & 1 \\
\hline $\begin{array}{l}1 \dagger \\
2 \\
3 \\
4 \\
5 \\
\end{array}$ & $\begin{array}{l}6 \text { June } \\
23 \text { June } \\
1 \text { July } \\
8 \text { July } \\
15 \text { July } \\
\text { Avg. ( } \pm \text { 1 SD) }\end{array}$ & $\begin{array}{r}12.4 \\
8.4 \\
14.0 \\
14.3 \\
12.8 \\
12.4(2.4)\end{array}$ & $\begin{array}{l}25 \\
55 \\
54 \\
19 \\
21 \\
35(18)\end{array}$ & $\begin{array}{c}166 \\
177 \\
126 \\
67 \\
99 \\
127(46)\end{array}$ & $\begin{array}{l}13.0 \\
11.6 \\
17.9 \\
11.8 \\
15.7 \\
14.0(2.7)\end{array}$ & $\begin{array}{c}3 \\
4 \\
4 \\
4 \\
10 \\
5(3)\end{array}$ & $\begin{array}{l}3 \\
5 \\
8 \\
8 \\
9 \\
7(3)\end{array}$ \\
\hline
\end{tabular}

† Samples in this plot were collected from the $0-$ to $15-\mathrm{cm}$ soil depth.

(1985) measured $\mathrm{N}_{2} \mathrm{O}$ emission of up to $10.31 \mathrm{~kg}$ $\mathrm{N}_{2} \mathrm{O}-\mathrm{N} \mathrm{ha}{ }^{-1}$ in a 151-d sample period in manureamended tobacco (Nicotiana tabacum L.). Obviously, the short-term loss of $\mathrm{N}_{2} \mathrm{O}-\mathrm{N}$ from manured fields immediately after rainfall can be of the same or greater magnitude as estimates of $\mathrm{N}_{2} \mathrm{O}-\mathrm{N}$ loss extrapolated from periodic daily measurements over an extended period. Although we measured greater rates of $\mathrm{N}_{2} \mathrm{O}$ loss than other studies have reported, we did not investigate whether these losses continued for an extended period. Consequently, the short-term measurements we conducted may not reflect $\mathrm{N}_{2} \mathrm{O}$ loss, even a few hours after rain stops.

Eichner (1990) estimated that $2 \%$ of $\mathrm{N}$ fertilizer is lost as $\mathrm{N}_{2} \mathrm{O}$ over a 1-yr period in fertilized and manured soils. The estimated $\mathrm{N}$ loss due to $\mathrm{N}_{2} \mathrm{O}$ emission in our study represented between 0.3 and $0.7 \%$ of the total $\mathrm{N}$ applied in the poultry manure. The values we measured support Eichner's conclusion that $\mathrm{N}_{2} \mathrm{O}$ emission accounts for a relatively small fraction of $\mathrm{N}$ fertilizer applied to agricultural soil (Eichner, 1990).

It is a tacit assumption on our part that the principal source of $\mathrm{N}_{2} \mathrm{O}$ in this study came from denitrification. Although the intensity and duration of rain created conditions favorable for denitrification, we cannot rule out other microbial sources of $\mathrm{N}_{2} \mathrm{O}$. Nitrous oxide may be evolved during $\mathrm{NO}_{3}^{-}$respiration (Smith and Zimmerman, 1981) and during autotrophic and heterotrophic nitrification (Robertson and Tiedje, 1987). Bremner and Blackmer (1981) reported that nitrification caused evolution of approximately $1.2 \mathrm{mg} \mathrm{N}_{2} \mathrm{O}-\mathrm{N} \mathrm{kg}^{-1}$ soil d ${ }^{-1}$ from soil amended with poultry manure and incubated at $50 \%$ water holding capacity and $30^{\circ} \mathrm{C}$.

We did not selectively inhibit nitrification. However, it is unlikely that nitrification was a major source of $\mathrm{N}_{2} \mathrm{O}$ during our measurements. Oxygen diffusion limits this process when water-filled pore space begins to exceed 60\% (Davidson, 1991). In manure-amended soil, the average gravimetric moisture content immediately after rainfall was $34.6 \%$ (SD $\pm 2.9 \%$ ) and water-filled pore space ranged between 69 and $87 \%$ (avg., $76 \pm 9 \%$ ). In grass filters the average gravimetric moisture content was $34.4 \%$ (SD $\pm 4.5 \%)$ and water-filled pore space ranged from 64 to $91 \%$ (avg., $76 \pm 10 \%$ ). Soil moisture conditions were clearly unfavorable for nitrification and the most likely source of $\mathrm{N}_{2} \mathrm{O}$ in our study was from denitrification. 
To see whether poultry manure stimulated $\mathrm{N}_{2} \mathrm{O}$ production, we compared $\mathrm{N}_{2} \mathrm{O}$ loss in manure-amended and unamended soil that were subjected to the same rainfall conditions. Nitrous oxide loss was significantly greater $(P \leq 0.01)$ in the manure-amended soil than the unamended soil. In contrast to the amended soil, $\mathrm{N}_{2} \mathrm{O}$ loss in unamended soil was only 0.5 to $5.6 \mathrm{mg} \mathrm{N}_{2} \mathrm{O}-\mathrm{N} \mathrm{m}^{-2}$ $h^{-1}$ (Table 2). We didn't measure $\mathrm{NO}_{3}^{-}$concentrations in unamended soil before rain simulations, but we assume that due to the short period between incorporation and simulation, nitrification would have contributed little to differences in soil $\mathrm{NO}_{3}^{-}$between amended and unamended locations.

The $\mathrm{N}_{2} \mathrm{O}$ losses we measured in the field were comparable to $\mathrm{N}_{2} \mathrm{O}$ losses Rice et al. (1988) measured in cell waste-amended, acetylene blocked soil cores. They noted that organic wastes injected into soil stimulated denitrification by providing available $\mathrm{C}$ and $\mathrm{N}$. Denitrification in most soils is C-limited and poultry manure represents the addition of potentially available $\mathrm{C}$ and $\mathrm{N}$. The mean potential denitrification in glucose-amended, manure-treated soil $\left(1.4 \mu \mathrm{g} \mathrm{N}_{2} \mathrm{O}-\mathrm{N} \mathrm{min}^{-1} \mathrm{~kg}^{-1}\right.$ soil) was only slightly greater than $\mathrm{NO}_{3}^{-}$-amended soil $(0.9 \mu \mathrm{g}$ $\mathrm{N}_{2} \mathrm{O}-\mathrm{N} \min ^{-1} \mathrm{~kg}^{-1}$ soil) or an unamended control (1.3

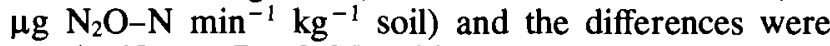
not significant $(P=0.05)$. This suggests that after poultry manure amendment, although $C$ may still have been limiting, there was sufficient $\mathrm{C}$ already present in the manure-treated plots to minimize the effect of $\mathrm{NO}_{3}^{-}$and glucose addition.

Significant $\mathrm{N}_{2} \mathrm{O}$ evolution from grass filters intercepting runoff from manure-amended soil (an edge-offield effect) could indicate a route by which $\mathrm{NO}_{3}^{-}$is removed from surface runoff before it contributes to nonpoint-source pollution. One of our objectives was to look for evidence that this occurred in field conditions.

Although the total sediment intercepted by the grass filters differed between plots (data not shown), there was not a significant difference $(P \leq 0.25)$ between the length of tilled strips and the amount of soil that eroded from them onto the abutting grass filters. There was also not a significant difference $(P \leq 0.54)$ between the length of tillage strip and $\mathrm{N}_{2} \mathrm{O}$ loss from the grass filters, whether from those portions that received runoff or those that did not. Nitrous oxide loss, however, was significantly greater $(P \leq 0.01)$ in parts of the grass filters that abutted the tillage strips compared with losses in downslope locations (Table 2).

We did not measure the runoff constituents, but Westerman et al. (1983) reported that runoff constituents from surface-applied poultry manure in a laboratory study under approximately similar conditions to ours $(9 \%$ slope, $5 \mathrm{~cm} \mathrm{~h}^{-1}$ simulated rain, $27 \mathrm{Mg} \mathrm{ha}^{-1}$ application rate) were $19 \mathrm{mg} \mathrm{L}^{-1} \mathrm{NH}_{4}^{+}-\mathrm{N}$ and $1.3 \mathrm{mg} \mathrm{L}^{-1} \mathrm{NO}_{3}-\mathrm{N}$. Chemical oxygen demand (COD) was $1875 \mathrm{mg} \mathrm{L}^{-1}$. Groffman et al. (1991) proposed that addition of a C and $\mathrm{N}$ source (like manure) to a filter strip might increase its denitrification potential. Our results appear to support that conclusion, at least with respect to $\mathrm{N}_{2} \mathrm{O}$ loss, although our study is not an absolute test of this hypothesis. Since every grass filter received runoff from manure-amended soil, we cannot say definitively that increased $\mathrm{N}_{2} \mathrm{O}$ loss was due to manure in runoff.

Nitrous oxide loss was significantly greater $(P \leq 0.01)$ in manure-amended tillage strips than in grass filters intercepting their runoff (Table 2). Since average gravimetric water content immediately after rainfall was similar (34.6 vs. $34.4 \%)$ and average water-filled pore space was identical $(76 \%)$, the difference is probably due to the initial soil $\mathrm{NO}_{3}^{-}$concentration in both locations (Table 3 ).

It is possible that more $\mathrm{N}_{2} \mathrm{O}$ was reduced to $\mathrm{N}_{2}$ in grass filters than tillage strips. This would result in less measurable $\mathrm{N}_{2} \mathrm{O}$ loss. When conditions were ideal for activity and $\mathrm{N}_{2} \mathrm{O}$ reduction was inhibited by acetylene, denitrification in the potential denitrification enzyme assays was significantly greater $(P<0.05)$ in unamended soil from the grass filters $\left(2.0 \mu \mathrm{g} \mathrm{N} \mathrm{N}_{2} \mathrm{O}-\mathrm{N} \mathrm{min}{ }^{-1} \mathrm{~kg}^{-1}\right.$ soil) compared to unamended soil from the tillage strips (1.3 $\mu \mathrm{g} \mathrm{N}_{2} \mathrm{O}-\mathrm{N} \mathrm{min} \mathrm{mg}^{-1} \mathrm{~kg}^{-1}$ soil). The $\mathrm{N}_{2} \mathrm{O}$ production rates we observed were about half the rate reported by Smith and Tiedje (1979) for similar assays on a loam soil.

Nitrate addition alone did not increase denitrification in soil from the grass filters. The potential denitrification activity remained at $2.0 \mu \mathrm{g} \mathrm{N}_{2} \mathrm{O}-\mathrm{N} \mathrm{min}^{-1} \mathrm{~kg}^{-1}$ soil. A much greater effect occurred when the grass filter soils were amended with glucose. The potential denitrification assays indicated that $\mathrm{N}_{2} \mathrm{O}$ production significantly increased (to $4.2 \mu \mathrm{g} \mathrm{N} \mathrm{N}_{2} \mathrm{O}-\mathrm{N} \mathrm{min}^{-1} \mathrm{~kg}^{-1}$ soil) when the soils were amended with glucose $(P<0.05)$. This suggests that grass filter soil was $C$-limited to a greater extent than was tillage strip soil.

These results did not correspond with the MPN denitrifiers enumerated for these soil samples. The mean tabulated value for MPN denitrifiers was greater in the tillage strip soil $\left(7.3 \times 10^{5}\right.$ cells $\mathrm{g}^{-1}$ soil $)$ than the grass filter soil $\left(5.5 \times 10^{5}\right.$ cells $\mathrm{g}^{-1}$ soil $)$. However, population estimates based on MPN are imprecise and small differences are not significant. The denitrifier numbers were statistically the same within the $95 \%$ confidence limit $( \pm 3.3 \times$ tabulated MPN).

\section{CONCLUSION}

Nitrous oxide evolution is a dynamic, microbially mediated process. We found that the average $\mathrm{N}_{2} \mathrm{O}$ loss immediately after rain could exceed $13 \mathrm{mg} \mathrm{N}_{2} \mathrm{O}-\mathrm{N} \mathrm{m}^{-2}$ $\mathrm{h}^{-1}$ in a well-drained silt loam soil amended with an available $\mathrm{C}$ and $\mathrm{N}$ source like poultry manure. The manure addition stimulated $\mathrm{N}_{2} \mathrm{O}$ loss compared with controls; however, it accounted for $<0.1 \%$ of the total $\mathrm{N}$ added in the manure. Although the potential denitrification activity in grass filters was greater than that in tilled soils, the $\mathrm{N}_{2} \mathrm{O}$ loss immediately after rainfall was less, probably as a result of the available $\mathrm{NO}_{3}^{-}$in soil in both locations. Grass filters intercepting runoff from poultry manureamended soils produced significantly more $\mathrm{N}_{2} \mathrm{O}$ than areas that did not intercept runoff. Consequently, there appears to be an edge-of-field effect for $\mathrm{N}_{2} \mathrm{O}$ loss, which contributes to some $\mathrm{NO}_{3}^{-}$removal from surface runoff of manure-treated soils. 


\section{ACKNOWLEDGMENTS}

We thank Lloyd Dunn, Rebecca Gilfillen, C. Elizabeth Madison, Murali Murageshi, and Roger Rhodes for their technical assistance during rainfall simulations and laboratory analyses. The work on which this report is based was supported, in part, by the U.S. Department of the Interior, under the provisions of Public Law 101-397, as Kentucky Water Resources Institute Report Number 188. Additional support was provided by Kentucky State Senate Bill 271. It is published with permission of the Director of the Kentucky Agricultural Experiment Station as journal article no. 94-3-11.

\section{REFERENCES}

Alexander, M. 1982. Most probable number method for microbial populations. p. 815-820. In A.L. Page et al. (ed.) Methods of soil analysis. Part 2. 2nd ed. Agron. Monogr. 9. ASA and SSSA, Madison, WI.

Blevins, R.L., W.W. Frye, P.L. Baldwin, and S.D. Robertson. 1990. Tillage effects on sediment and soluble nutrient losses from a Maury silt loam soil. J. Environ. Qual. 19:683-686.

Bremner, J.M., and A.M. Blackmer. 1981. Terrestrial nitrification as a source of atmospheric nitrous oxide. p. 151-170. In C.C. Delwiche (ed.) Denitrification, nitrification, and atmospheric nitrous oxide. John Wiley \& Sons, New York

Cates, R.L., and D.R. Keeney. 1987. Nitrous oxide production throughout the year from fertilized and manured maize fields. J. Environ. Qual. 16:443-447.

Coyne, M.S., R.A. Gilfillen, and R.L. Blevins. 1994. Nitrous oxide flux from poultry-manured erosion plots and grass filters after simulated rain. J. Environ. Qual. 23:831-834.

Davidson, E. 1991. Fluxes of nitrous oxide and nitric oxide from terrestrial ecosystems. p. 219-235. In J.E. Rogers and W.B. Whitman (ed.) Microbial production and consumption of greenhouse gases. Am. Soc. Microbiol., Washington, DC.

Edwards, D.R., and T.C. Daniel. 1992. Environmental impacts of on-farm poultry waste disposal -a review. Bioresour. Technol. 41 9-33.

Eichner, M.J. 1990. Nitrous oxide emissions from fertilized soils: Summary of available data. J. Environ. Qual. 19:272-280.

Firestone, M.K., and J.M. Tiedje. 1979. Temporal change in nitrous oxide and dinitrogen from denitrification following onset of anaerobiosis. Appl. Environ. Microbiol. 38:673-679.

Goodroad, L.L., and D.R. Keeney. 1985. Site of nitrous oxide production in field soils. Biol. Fert. Soils 1:3-7.

Groffman, P.M., E.A. Axelrod, J.L. Lemunyon, and W. M. Sullivan. 1991. Denitrification in grass and forest vegetated filter strips. J. Environ. Qual. 20:671-674.

Hutchinson, G.L., and A.R. Mosier. 1981. Improved soil cover method for field measurements of nitrous oxide fluxes. Soil Sci. Soc. Am. J. 45:311-316.

Moore, I.D., M.C. Hirschi, and B.J. Barfield. 1983. Kentucky rainfall simulator. Trans. ASAE 26:1085-1089.

Mosier, A.R., and L. Klemedtsson. 1994. Measuring denitrification in the field. p. 1047-1065. In R.W. Weaver et al. (ed.) Methods of soil analysis. Part 2. SSSA Book Ser. 5. SSSA, Madison, WI.

Rice, C.W., P.E. Sierzega, J.M. Tiedje, and L.W. Jacobs. 1988. Stimulated denitrification in the microenvironment of a biodegradable organic waste injected into soil. Soil Sci. Soc. Am. J. 52: 102-108.

Robertson, G.P., and J.M. Tiedje. 1987. Nitrous oxide sources in aerobic soils: Nitrification, denitrification, and other biological processes. Soil Biol. Biochem. 19:187-193.

Smith, M.S., and J.M. Tiedje. 1979. Phases of denitrification following oxygen depletion in soil. Soil Biol. Biochem. 11:261-267.

Smith, M.S., and K. Zimmerman. 1981. Nitrous oxide production by nondenitrifying soil nitrate reducers. Soil Sci. Soc. Am. J. 45: $865-871$

Tiedje, J.M. 1982. Denitrification. p. 1011-1026. In A.L. Page et al. (ed.) Methods of soil analysis. Part 2. 2nd ed. ASA and SSSA, Madison, WI.

Westerman, P.W., T.L. Donnelly, and M.R. Overcash. 1983. Erosion of soil and poultry manure-a laboratory study. Trans. ASAE 26: $1070-1078,1084$ 